\title{
Cotton Hedging: A Comparison across Developing and Developed Countries
}

\author{
Qizhi Wang, Benaissa Chidmi \\ Ag. \& Applied Economics, Texas Tech University, Lubbock, USA \\ E-mail: Benaissa.chidmi@ttu.edu \\ Received April 26, 2011; revised June 15, 2011; accepted July 2, 2011
}

\begin{abstract}
This paper uses the results of ordinary least squares, bivariate vector autoregressive, and error correction models to estimate the hedge ratios for cotton production across different countries and to determine whether New York Cotton Exchange futures prices can serve as a hedging tool for cotton producers. Models comparison shows that the error correction model fits the data better. The results of the error correction model show that the spot prices and the NYCE futures prices are co-integrated in United States, Australia, and China, but not in Africa Franc Zone countries. In addition, for countries with higher market power, such as US and China, and countries without market distortions, such as Australia, the New York Cotton Exchange futures prices can serve as a hedging tool for cotton producers. In contrast, for less developed countries, such as Africa Franc Zone countries, and Pakistan, the NYCE futures prices cannot serve as hedging tool against the risks faced by cotton farmers.
\end{abstract}

Keywords: Cotton, Hedge Ratio, Error Correction Model

\section{Introduction}

Cotton is one of the major natural fibers. It accounts for around 40 percent of the world's annual textile fiber production and serves as an engine of economic growth by providing income to millions of farmers in both developed and developing countries worldwide. Between 1 and 2 million households produce cotton in West Africa, and up to 16 million people are involved in cotton production in some way (International Cotton Advisory Committee, 2007). The contribution of cotton to national gross domestic product (GDP) varies among countries. For instance, cotton provides 3 to 5 percent of the GDP in Benin, Burkina Faso, Mali, and Chad. In addition, cotton's exports generate significant resources for national economies. For example, in Burkina Faso, Benin, Chad, Mali, and Togo, cotton export share in total exports represents 51.4 percent, 37.6 percent, 36.2 percent, 25 percent and 11.2 percent, respectively (Hussein, Hitimana, and Perret, 2005) [1]. Cotton also plays an important role in the United States. The United States produces about 20 percent of the world's cotton supply and consumes about 10 percent of world cotton. Cotton provides about 0.1 percent of U.S. GDP (Irwin, 2001) [2]. The importance of the cotton trade is also evident in that much of the world's cotton crosses international borders more than once before reaching its final consumers (MacDonald, 2000) [3].

In recent years, several policy and technology changes in the textile industry have affected the cotton market and world cotton trade. In 2005, world textile trade began to operate under the Agreement on Textiles and Clothing (ATC) instead of the Multi Fiber Agreement (MFA). Based on that new rule, all quotas in the cotton textile industry were eliminated. In 2001, China was admitted into the World Trade Organization (WTO) and became a major player in the textile industry. China has continued to increase its share of world mill consumption, which jumped from 27 percent in 2001 to 42 percent in 2008 (Foreign Agricultural Service (FAS), 2008) [4].

Another important change has been the dramatic increase in grain prices that has accompanied the expansion of biofuel production in the United States, Europe, and South America. Because cotton must compete for space with corn, soybeans, and other crops, it is reasonable to think that planted areas of cotton in some major cotton producing countries will decrease. This is indeed the case in the US: the harvested areas of cotton decreased 7.8 percent in 2006/07 from 2005/06 levels, 17.6 percent in 2007/08 down from 2006/07, and 22.8 percent 
in 2008/09, down from 2007/08 (FAS, 2008) [4]. The total harvested areas of cotton decreased around 2.3 million hectares, which is more than the total cotton harvesting area in the Africa Franc Zone countries. The increase in India's cotton production due to the adoption of Bt cotton, which made India the second largest cotton exporter in the world, with 24 percent of world cotton trade (FAS, 2008) [4] is another key factor in cotton industry.

Finally, exchange rate volatility and monetary policy in many countries influence cotton production and price levels. For example, the devaluation of the CFA franc in January 1994 by 100 percent against the French franc boosted cotton production in CFA countries, augmented by a strong U.S. dollar that climbed to a peak against the Euro in February 2002. However, this trend has since reversed, affecting the profitability of cotton production in the African Franc Zone (Estur, 2004) [5]. Based on an orderly correction in the US current account deficit in 2006, the World Bank expected an annual 5 percent effective decline in the US currency through 2008 (Business News, 2006) [6].The long term depreciation of the US dollar reflects the long term decline in commo- dity prices, and also the world's historically higher rates of inflation. On the other hand, appreciation of Chinese currency would also increase the cost of textile exports and as a result, would decrease Chinese cotton imports. These new trends in the world cotton market indicate that the cotton price will remain volatile. Some of these trends may cause an increase in the world price of cotton, while others trends may reduce it.

World cotton prices have fluctuated widely in the last sixty years. Figure 1 presents the world cotton Cotlook A-index prices and the New York Cotton Exchange (NYCE) near December contract price over the last 30 years. From Figure 1, one can see that both the Cotlook A-index price and the NYCE near December contract price follow the same pattern, with a low price of approximately 40 cents per pound in 2001/02 and a high of around 94 cents per pound in 1994/95. During the most recent 5 years, the price of cotton has been as low as 50.54 cents per pound in 2004/05 and as high as 73 cents per pound in $2007 / 08$.

Due to price volatility, some countries, such as those in the Africa Franc Zone, are losing export earnings of about $\$ 1$ billion a year in direct and indirect costs as a result of subsidies paid by the United States and European Union (World Trade Organization, 2003) [7]. At the same time, exchange rate movements pose an additional risk to be managed, because of additional pressure

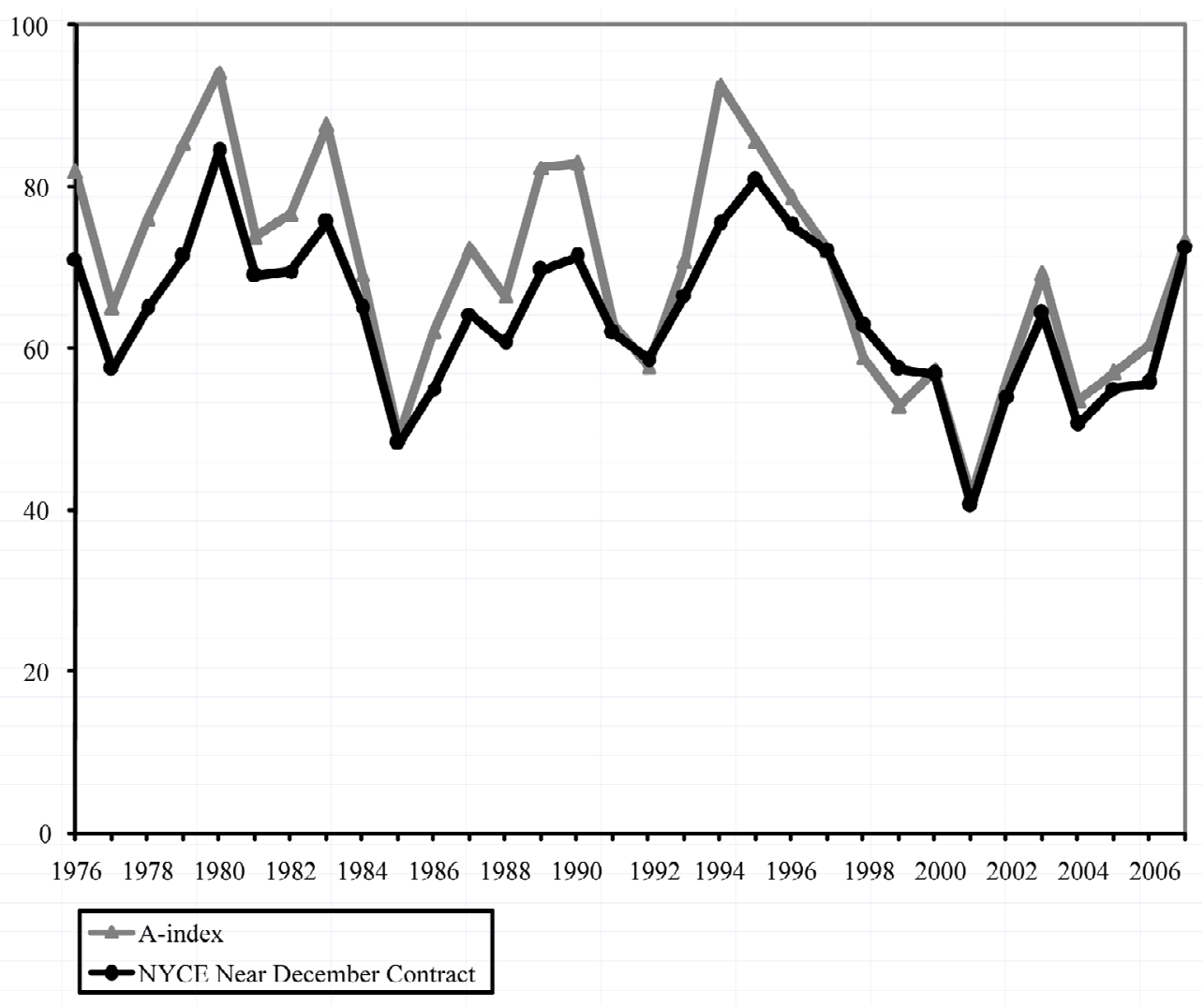

Figure 1. World Cotton A-Index and NYCE near December Contract. 
on cotton producers and exporters when exchange rates are volatile. All these factors increase the exposure of the African countries in particular, and less developed countries in general, to the risk involved in producing cotton.

Presently, cotton producers in developing countries such as the African Franc Zone countries make very limited use of risk management instruments to hedge their exposure. Commodity cash prices are more variable than futures prices. Futures and options may provide the most efficient way to deal with short-term price uncertainty (Varangis et al., 1994) [8]. In addition, futures and options contracts can allow more flexibility in selling decisions. Therefore, hedging is useful in the cotton market. There are, however several obstacles that must be overcome in order to make use of hedging in The African Franc Zone countries. First, the market in agricultural products in both developed and developing countries is not totally free and markets are not fully developed especially in developing countries. Second, there is a lack of technical skills the use of risk management instruments in developing countries. Although some governments could make good use of hedging instruments to reduce cotton price volatility, this practice only provides partial coverage. Finally, the costs of hedging, i.e., the cost to obtain data and information, may also impede the implementation of hedging policies.

A logical question that comes to the researcher and policy maker's mind is whether hedging instruments, as used in developed countries, could be optimized to hedge against the risks involved in producing cotton in less developed and developing countries. Therefore, the objective of this paper is to determine the relationship between the NYCE cotton futures price and domestic farm prices in African Franc Zone and other less developed countries and compare it with the one prevailing in other countries, such as the United States, China, and Australia. This will shed light on how the changes in NYCE prices are reflected in the changes in domestic prices, as well as whether NYCE prices can be used to hedge cotton production in these countries.

The rest of this paper is organized as follows. In the next section, we present a conceptual framework. Section three presents the methods and procedures used to estimate the conceptual framework; while section four presents the data used. In section five, we discuss the findings of the paper, and in section six we conclude.

\section{Conceptual Framework}

This section focuses on theoretical construction of the hedging ratio. Cotton producers face substantial income risk due to price fluctuations. Apart from government price support schemes, such as counter cyclical payments, the loan rate, and other programs as used in the United States, a number of alternative market-based techniques are practiced to deal with these income risks. For example, farmers can spread their sources of income by cultivating various crops, or/and storing harvested outputs in order to sell commodities during a high-price period instead of a low-price period. It has been shown that stockholding is an important device for small holders to reduce price risks (Zant, 1998) [9].

A financial risk management instrument is a technique that hedges price risks on futures exchanges. These types of instruments have received increased attention in recent policy discussions (World Bank, 1999) [10]. With respect to the use of these instruments, questions such as the costs of hedging price risks and the size of the welfare gains to be obtained from using such tools are often raised.

Consider a farmer who will harvest cotton at a known date in the future. The price at which the cotton will be sold at a given date is uncertain; hence, the profit from cotton production is stochastic. We assume that the farmers only consider the present and some future "terminal" date. That is, the cotton producer is a myopic agent (Johnson 1960 [11], Stein, 1961 [12], Holthausen, 1979 [13]) such that his decision horizon equals his planning horizon. The farmer cannot revise his cash or hedging position between the time of placing the hedge and the time when it is liquidated. Based on these assumptions, farmers' production decisions are executed at two distinct dates. At time 1, the output price is not known with certainty. It is assumed that farmers can hedge the risk associated with the output price uncertainty by taking positions in the futures market. At time 2, the uncertainty about the output price is resolved, and the farmers choose the level of hedging conditional on the open futures and options position determined at time 1 .

To compare the efficiency of different risk management methods, especially whether farmers adopt the New York near December contract crop year average cotton price to hedge or not, the risk-minimizing strategies are considered. It is assumed that farmers choose a best risk management strategy based on a risk comparison among different choices. That is, farmers will look at the additional risk of a given strategy relative to the optimal one. Following Lence et al. (1993) [14], a benchmark in the hedging literature is the static minimum variance hedge ratio (SMV). The SMV is the proportion of the cash position to be hedged in order to minimize the variance of terminal wealth, for a given cash position. The SMV is important, because it represents the optimal hedge ratio for myopic agents who are extremely risk averse (Ederington 1979 [15]; Kahl 1983 [16]).

Moreover, the SMV is the optimum hedge ratio when 
futures prices are unbiased (Benninga et al., 1983) [17], yet easy to estimate empirically and provides a handy operational tool (Lence et al., 1993) [14]. Under this framework, hedging will be defined as holding $x$ units of spot market $i$ and $z$ units of future market $j$ such that the price risk of holding $x$ and $z$, from time $t_{1}$ to $t_{2}$ is minimized. Spot is defined to be cash market holdings. ${ }^{1}$ If the basis is constant, the hedger will be easily able to offset all his risk by taking an equally large position in the futures market as his planned transaction. When a hedge ratio is 1 , his losses or gains in the cash market will be perfectly offset by his losses or gains in the future market. In reality, basis is not stable and the hedger has to weigh together the price risk and the basis risk. In mathematical terms, a risk averse farmer's objective is to choose the hedge ratio, $H_{0}^{*}$, that minimizes the variance of terminal wealth, given the information currently available:

$$
\min _{H_{0}} \operatorname{var}_{0}(\pi)
$$

where $\pi$ is the expected profit at time $t$ for cotton producer given by:

$$
\begin{gathered}
\pi=\left(F P_{2}-F P_{1}\right) z+\left(C P_{2}-C P_{1}\right) x-C(X) \\
X=z+x
\end{gathered}
$$

where $F P_{j}$ is the futures price quoted at date $j(j=1,2)$ for delivery at date $2 ; z$ is the future position taken at date $1, x$ is the known cash position, $C P_{j}$ is the cash price for cotton at date $(j=1,2)$, and $C(X)$ is the cost function for production of $X$ units of cotton.

The farmer's objective is to minimize the risk as measured by the variance of the profit in (2). According to Mathews and Holthausen (1991) [13], the mean-variance framework is more understandable and requires less information than a full expected-utility-maximizing model, and mean-variance models are equivalent to expected utility maximization. The farmer minimizes the variance of profit $\sigma_{\pi}^{2}$, holding output $X$ fixed by choosing the hedge $z$, and solves the variance

$$
\min \sigma_{\pi}^{2}=\min \left[z^{2} \sigma_{f}^{2}+x^{2} \sigma_{c}^{2}-2 z \sigma_{c f}\right]
$$

where $\sigma_{f}^{2}$ is the variance of futures price $F_{j}, \sigma_{c}^{2}$ is the variance of spot prices $\mathrm{C}, \sigma_{c f}$ is the covariance between futures prices $\mathrm{F}$ and spot prices $\mathrm{C}$. Assuming $\mathrm{C}(\mathrm{X})$ is constant, the first order condition for (4), with respect to the position in the future is

$$
2 \sigma_{f}^{2}-x \sigma_{c f}=0
$$

Therefore, the minimum risk hedge ratio is

$$
h_{0}^{*}=\frac{z}{x}=\frac{\sigma_{c f}}{\sigma_{f}^{2}}
$$

${ }^{1}$ Basis is the term used for the difference between the spot and the futures price (Jones 1968 [18]).
In other words, the hedge ratio is:

$$
h_{0}^{*}=\frac{\text { cov ariance of spot and future price }}{\text { var iance of futures price }}
$$

This formula is well known in the literature (Kahl, 1983) and is called the standard hedge ratio (Mathews and Holthausen, 1991) [19]. $h$ is a hedge ratio, which is the proportion of the physical position being hedged. And the amount hedged in the market by the farmer is $h^{*} x$. If the basis is constant, the variance and the covariance will be the same and a minimum of the hedge ratio can be reached at $h=1$. If the two prices are uncorrelated, the optimal value must be reached at $h=0$.

\section{Methods and Procedures}

\subsection{Model Specification}

In order to estimate the minimum variance of hedge ratios for the major cotton producers and choose the optimal hedging ratios, we assume that the hedging is performed using the New York futures near December contract cotton crop year average prices. Following the literature, we compare three different models to calculate the optimal hedge ratios and the minimum variance: 1) The ordinary least squares (OLS) model, 2) the bivariate vector autoregressive (VAR) model, and 3) the error correction model.

The first model is the traditional OLS model. Based on the literature (Leuthold et al., 1989) [20], ex post minimum variance hedge ratios are typically estimated with the following ordinary least squares regression:

$$
\Delta C P_{t}=\alpha+\beta \Delta F P_{t}+\varepsilon_{t}
$$

where $\triangle C P$, and $\triangle F P$, are the change in the spot price (CP) and futures price (FP), respectively, over interval $t$. The parameter $\beta$ is the ex post minimum variance hedge ratio, $\alpha$ is the systematic trend in cash prices, and $\varepsilon$ is the residual basis risk.

The second model is the bivariate VAR model. According to Herbst et al. (1989) [21], one aspect of the above regression model's invalidity is the fact that the residuals are auto correlated. In order to eliminate the serial correlation, the spot and futures prices are modeled under a bivariate-VAR framework as follows:

$$
\begin{aligned}
& \Delta C P_{t}=\alpha_{c}+\sum_{i=1}^{k} \beta_{s i} \Delta C P_{t-i}+\sum_{i=1}^{k} \gamma_{s i} \Delta F P_{t-i}+\varepsilon_{c t} \\
& \Delta F P_{t}=\alpha_{f}+\sum_{i=1}^{k} \beta_{f i} \Delta C P_{t-i}+\sum_{i=1}^{k} \gamma_{f i} \Delta F P_{t-i}+\varepsilon_{f t}
\end{aligned}
$$

where $\alpha$ is the intercept, and $\beta_{s i}, \beta_{f i}, \gamma_{s i}$, and $\gamma_{f i}$ are positive parameters. $\varepsilon_{c t}$ and $\varepsilon_{f t}$ are independently identically distributed (i.i.d) random vectors. If we let var 
$\left(\varepsilon_{c t}\right)=\sigma_{s s}, \operatorname{var}\left(\varepsilon_{f t}\right)=\sigma_{f f}$, and $\operatorname{cov}\left(\varepsilon_{c t}, \varepsilon_{f t}\right)=\sigma_{s f}$, many previous studies (Yang and Allen, 2005) [22] have shown that the minimum variance hedge ratio is

$$
h^{*}=\sigma_{s f} / \sigma_{f f} .
$$

The third model is the error-correction model. Based on Ghosh (1993) [23], Lien and Luo (1994) [24] and Lien (1996) [25], the second model described above ignores co-integration between two price series. According to their suggestions, if two series are co-integrated, a VAR model should be estimated along with the errorcorrection term which accounts for the long-run equilibrium between spot and futures price movements. Therefore the second model should be modified as follows:

$$
\begin{aligned}
& \Delta C P_{t}=\alpha_{c}+\sum_{i=1}^{k} \beta_{s i} \Delta C P_{t-i}+\sum_{i=1}^{k} \gamma_{s i} \Delta F P_{t-i}+\tau_{s} Z_{t-1}+\varepsilon_{c t} \\
& \Delta F P_{t}=\alpha_{f}+\sum_{i=1}^{k} \beta_{f i} \Delta C P_{t-i}+\sum_{i=1}^{k} \gamma_{f i} \Delta F P_{t-i}+\tau_{f} Z_{t-1}+\varepsilon_{f t}
\end{aligned}
$$

$Z_{t-1}$ is the error-correction term, which measures how the dependent variable adjusts to the previous period's deviation from long-run equilibrium, according to the following expression:

$$
Z_{t-1}=C P_{t-1}+\delta F P_{t-1}
$$

where $\delta$ is the co-integrating vector. This two-variable error-correction model expressed in equation (11) is a bivariate $\operatorname{VAR}(k)$ model in first differences augmented by the error-correction term $\tau_{s} Z_{t-1}$ and $\tau_{f} Z_{t-1}$. The coefficients $\tau_{s}$ and $\tau_{f}$ are interpreted as speed of adjustment parameters. The larger $\tau_{s}$ is, the greater the response of $C P_{t}$ to the previous period's deviation from long-run equilibrium.

\subsection{Model Selection}

In order to compare the performances of each type of hedging strategy, the un-hedged portfolio is constructed, consisting of shares with the same proportion as the share price index held on the spot market. The hedged portfolio is also constructed, consisting of a combination of the share price index held on both the spot and the futures markets. The number of futures contracts held is determined by the computed hedge ratios from each hedging strategy. The hedging performance is compared in terms of the risk-return trade-off, and the percentage variance reduction in the hedged portfolio relative to the un-hedged portfolio.

According to Baillie and Myers (1991) [26], and Park and Bera (1987) [27], the returns on the un-hedged portfolio and the hedged portfolio are simply expressed as:

$$
r u=C P t+1-C P t
$$

$$
r h=(C P t+1-C P t)-h *(F P t+1-P f t)
$$

where $r u$ and $r h$ are return on un-hedged portfolio and hedge portfolio, respectively. Ft and $C_{t}$ are logged futures and spot prices at time period $t$, respectively, and $h^{*}$ is the optimal hedge ratio. The return on the hedged portfolio is the difference between the return on holding the cash position and corresponding futures position. Similarly, the variances of the un-hedged and the hedged portfolios are expressed as:

$$
\begin{gathered}
\operatorname{Var}(U)=\sigma_{c}^{2} \\
\operatorname{Var}(H)=\sigma_{c}^{2}+h *^{2} \sigma_{f}^{2}-2 * h * \sigma_{c . f}
\end{gathered}
$$

where $\operatorname{Var}(U)$ and $\operatorname{Var}(H)$ represent variances of unhedged portfolio and hedged portfolio, respectively. $\sigma_{c}$, $\sigma_{f}$ are standard deviation of the spot and futures price, respectively; and $\sigma_{c, f}$ represents the covariance of the spot and futures price.

According to Ederington (1979) [15], the effectiveness of hedging can be measured by the percentage of the reduction in variance of the hedged portfolio relative to the un-hedged portfolio. The variance reduction can be calculated as:

$$
\frac{\operatorname{Var}(U)-\operatorname{Var}(H)}{\operatorname{Var}(U)}
$$

The larger the variance reduction is, the better is the hedging strategy. That is, the better hedging strategy chosen has to provide more reduction of the variance compared to the variance of the spot price in the cotton market with the un-hedged strategy.

\section{Data Sources and Estimation Issues}

The data sets used in the studies come from different sources. The primary data source is the cost of production of raw cotton, published by International Cotton Advisory Committee. Other sources include reports from the USDA foreign Agricultural Service, Food and Agriculture Organization, the World Bank, and personal contacts in the different countries.

Table 1 presents the descriptive statistics for the twelve major cotton producers' domestic farm prices collected in the past thirty years, as well as the New York Future market price. It shows that cotton price distributions are quite different among countries. The average cotton price in the United States, Australia and China is closer to the New York Futures Market price; while the Africa Franc Zone countries and Pakistan have a lower average price than the other countries. Due to the lack of record-keeping, there are only 28 years cotton price data to collect from the Africa Franc zone countries like Benin and Chad, and only 19 years of recorded cotton prices for Brazil. 
Table 1. Descriptive Statistics of Domestic and the New York Futures Price.

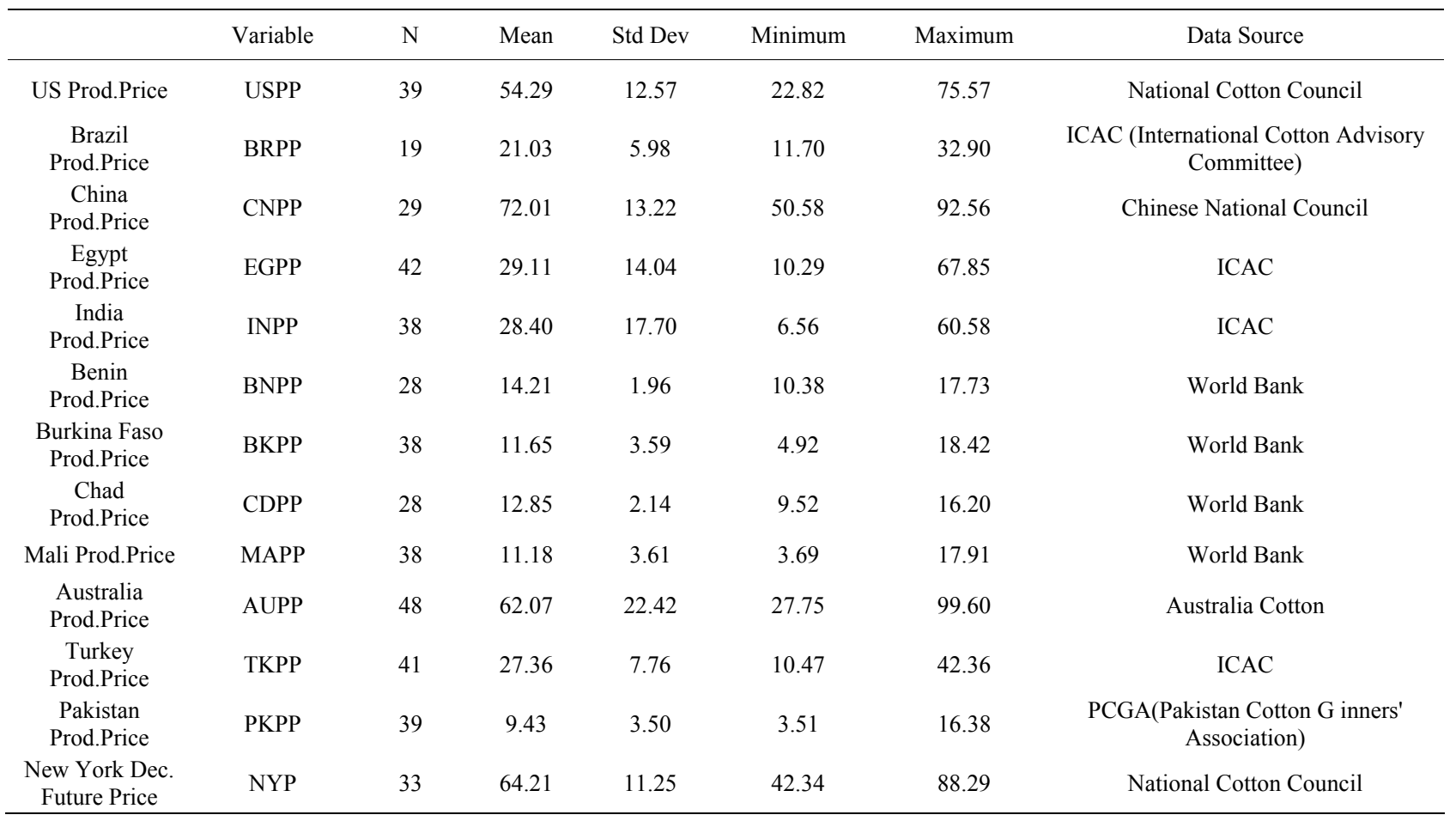

Table 2 shows that cotton prices in the United States, Australia, China and Turkey strongly correlate with the New York Future Cotton price. On the contrary, the others, such as the Africa Franc Zone countries of Benin, Chad, and Mali, only weakly correlate with the New York Future Cotton price. The price of Egyptian cotton also demonstrates a weak correlation with the New York Future price is weak, which may be related to government interventions as discussed by Levy (1983) [28]. Based on Levy, export taxes, production taxes, and acreage restrictions and a heavily subsidized domestic textile industry are the main factors that explain the low relationship between cotton prices in Egypt and world cotton market. The correlation is even negative, but not statistically significant, in the case of India. In order to determine whether the time series are consistent with the stationary process and with a deterministic trend, we conduct a unit root analysis using the augmented DickeyFuller (ADF) test. For the bivariate VAR model, the unit root test is carried out under the null hypothesis $\gamma=0$ against the alternative hypothesis of $\gamma<0$. The DickeyFuller statistic given by $D F_{\tau}=\frac{\hat{\gamma}}{S E(\hat{\gamma})}$ is compared to the relevant critical value for the Dickey-Fuller test. The null hypothesis of $\gamma=0$ will be rejected and there is no unit root present if the test statistic is greater (in absolute value) than the critical value. In addition, we test for co-integration using the Johansen method.

\section{Results and Discussion}

\subsection{Unit Roots, Co-integration, and Model Selection Tests}

The results of the unit root test for NYCE and farm prices in different major cotton producing areas are reported in Table 3. The augmented Dicky-Fuller (ADF) test is used to account for temporally dependent and heterogeneously distributed errors by including lagged sequences of first differences of the variable in its set of regressors (Dickey and Fuller, 1981) [29].

The null hypothesis for the ADF test is that the variables contain a unit root or they are non-stationary at a certain significance level. The results of this test show that most of the time series are non-stationary as the ADF t-statistics are not statistically significant. After being differentiated once, they all become stationary. This means that the ADF t-statistics become significant. Therefore, it can be concluded that the NYCE futures and domestic farm prices are an integration of order one.

Table 4 presents the results of the Johansen and Juselius (1990) [30] co-integration test. The results of Johansen's co-integration have two tests, one designed to test for the presence of $r$ co-integrating vectors (the trace test), and the other designed to test the hypothesis of $r$ co-integrating vectors in $r+1$ co-integrating vectors (the maximum eigenvalue test). These two tests are undertaken on the NYCE and the domestic farm prices. When 
Table 2. Correlation Matrix between Domestic Cotton Prices and the New York Futures Cotton Price.

\begin{tabular}{ccc}
\hline Major Country cotton price & $\begin{array}{c}\text { New York Future Price } \\
\text { Correlation coefficient }\end{array}$ & p-Value \\
\hline U.S & 0.89 & $<0.0001$ \\
Brazil & 0.39 & 0.09 \\
China & 0.51 & 0.004 \\
India & -0.05 & 0.79 \\
Pakistan & 0.26 & 0.10 \\
Australia & 0.89 & $<0.0001$ \\
Turkey & 0.51 & 0.0008 \\
Egypt & 0.12 & 0.49 \\
Burkina Faso & 0.34 & 0.03 \\
Benin & -0.001 & 0.99 \\
Chad & 0.07 & 0.72 \\
Mali & 0.40 & 0.01 \\
\hline
\end{tabular}

Table 3. ADF Unit Root Tests.

\begin{tabular}{|c|c|c|c|c|c|}
\hline \multirow{2}{*}{ Country } & & \multicolumn{2}{|c|}{ Level } & \multicolumn{2}{|c|}{ First Difference } \\
\hline & & $\operatorname{lag}(0)$ & $\operatorname{lag}(1)$ & $\operatorname{lag}(0)$ & $\operatorname{Lag}(1)$ \\
\hline \multirow[t]{3}{*}{ US } & Zero mean & -0.06 & 0.07 & -7.44 & -4.88 \\
\hline & single mean & -3.26 & -3 & -7.4 & -4.88 \\
\hline & trend & -3.08 & -2.81 & -7.49 & -5.11 \\
\hline \multirow[t]{3}{*}{ Australia } & Zero mean & -0.33 & -0.14 & -8.26 & -7.2 \\
\hline & single mean & -2.3 & -2.03 & -8.21 & -7.19 \\
\hline & trend & -2.37 & -1.95 & -8.19 & -7.28 \\
\hline \multirow[t]{3}{*}{ China } & Zero mean & -0.56 & -0.58 & -6.13 & -5.44 \\
\hline & single mean & -2.98 & -3 & -6.01 & -5.34 \\
\hline & trend & -2.85 & -2.83 & -6.08 & -5.61 \\
\hline \multirow[t]{3}{*}{ India } & Zero mean & 0.15 & 0.49 & -7.49 & -7.69 \\
\hline & single mean & -1.26 & -0.99 & -7.63 & -8.32 \\
\hline & trend & -3.31 & -2.74 & -7.51 & -8.2 \\
\hline \multirow[t]{3}{*}{ Pakistan } & Zero mean & -0.85 & -0.98 & -6.51 & -3.55 \\
\hline & single mean & -0.91 & -0.8 & -6.51 & -3.58 \\
\hline & trend & -2.34 & -2.07 & -6.46 & -3.52 \\
\hline \multirow[t]{3}{*}{ Brazil } & Zero mean & 0.26 & 0.1 & -3.52 & -3.92 \\
\hline & single mean & -1.23 & -1.87 & -3.46 & -3.78 \\
\hline & trend & -0.91 & -1.53 & -3.58 & -4.37 \\
\hline \multirow[t]{3}{*}{ Egypt } & Zero mean & -0.8 & -0.61 & -7.69 & -3.72 \\
\hline & single mean & -2.36 & -2.06 & -7.6 & -3.66 \\
\hline & trend & -2.3 & -1.79 & -7.67 & -3.76 \\
\hline \multirow[t]{3}{*}{ Turkey } & Zero mean & -0.35 & -0.06 & -8.43 & -5.97 \\
\hline & single mean & -3.26 & -3 & -8.38 & -5.97 \\
\hline & trend & -3.24 & -3.09 & -8.44 & -6.18 \\
\hline \multirow[t]{3}{*}{ Benin } & Zero mean & -0.1 & -0.01 & -6.32 & -4.59 \\
\hline & single mean & -2.97 & -2.54 & -6.2 & -4.52 \\
\hline & trend & -3.18 & -2.8 & -6.07 & -4.43 \\
\hline \multirow[t]{3}{*}{ Burkina $\mathrm{F}$} & Zero mean & -0.17 & 0.3 & -9 & -5.65 \\
\hline & single mean & -2.6 & -2.18 & -9.03 & -5.76 \\
\hline & trend & -3.51 & -2.44 & -9.05 & -5.87 \\
\hline \multirow[t]{3}{*}{ Chad } & Zero mean & -0.21 & 0.1 & -5.49 & -4.1 \\
\hline & single mean & -2.51 & -2.76 & -5.41 & -4.06 \\
\hline & trend & -2.78 & -2.85 & -5.29 & -3.98 \\
\hline \multirow[t]{3}{*}{ Mali } & Zero mean & 0.27 & 0.47 & -6.97 & -4.79 \\
\hline & single mean & -2.22 & -2.23 & -7.09 & -4.98 \\
\hline & trend & -2.99 & -2.79 & -7.1 & -5.06 \\
\hline
\end{tabular}


Table 4. Johansen's Co-integration Test.

\begin{tabular}{|c|c|c|c|c|c|}
\hline Country & $\mathrm{H0}(\mathrm{rank}=r)$ & $\mathrm{H} 1(\mathrm{rank}>r)$ & Eigenvalue value Test & Trace Test & Critical Value (5\%) \\
\hline \multirow[t]{2}{*}{ US } & $r=0$ & $r>0$ & 0.45 & $19.24 *$ & 12.21 \\
\hline & $r=1$ & $r>1$ & 0.01 & 0.29 & 4.14 \\
\hline \multirow[t]{2}{*}{ China } & $r=0$ & $r>0$ & 0.37 & $13.22 *$ & 12.21 \\
\hline & $r=1$ & $r>1$ & 0.01 & 0.25 & 4.14 \\
\hline \multirow[t]{2}{*}{ Egypt } & $r=0$ & $r>0$ & 0.17 & 5.98 & 12.21 \\
\hline & $r=1$ & $r>1$ & 0.01 & 0.19 & 4.14 \\
\hline \multirow[t]{2}{*}{ India } & $r=0$ & $r>0$ & 0.11 & 3.90 & 12.21 \\
\hline & $r=1$ & $r>1$ & 0.00 & 0.00 & 4.14 \\
\hline \multirow[t]{2}{*}{ Australia } & $r=0$ & $r>0$ & 0.45 & $19.52 *$ & 12.21 \\
\hline & $r=1$ & $r>1$ & 0.01 & 0.37 & 4.14 \\
\hline \multirow[t]{2}{*}{ Turkey } & $r=0$ & $r>0$ & 0.39 & $15.92 *$ & 12.21 \\
\hline & $r=1$ & $r>1$ & 0.01 & 0.28 & 4.14 \\
\hline \multirow[t]{2}{*}{ Pakistan } & $r=0$ & $r>0$ & 0.08 & 3.52 & 12.21 \\
\hline & $r=1$ & $r>1$ & 0.03 & 0.86 & 4.14 \\
\hline \multirow[t]{2}{*}{ Brazil } & $r=0$ & $r>0$ & 0.24 & 5.03 & 12.21 \\
\hline & $r=1$ & $r>1$ & 0.00 & 0.07 & 4.14 \\
\hline \multirow[t]{2}{*}{ Benin } & $r=0$ & $r>0$ & 0.42 & $14.96^{*}$ & 12.21 \\
\hline & $r=1$ & $r>1$ & 0.00 & 0.06 & 4.14 \\
\hline \multirow[t]{2}{*}{ Burkina Faso } & $r=0$ & $r>0$ & 0.33 & $12.69^{*}$ & 12.21 \\
\hline & $r=1$ & $r>1$ & 0.00 & 0.00 & 4.14 \\
\hline \multirow[t]{2}{*}{ Chad } & $r=0$ & $r>0$ & 0.35 & $11.79^{*}$ & 12.21 \\
\hline & $r=1$ & $r>1$ & 0.00 & 0.10 & 4.14 \\
\hline \multirow[t]{2}{*}{ Mali } & $r=0$ & $r>0$ & 0.25 & 9.22 & 12.21 \\
\hline & $r=1$ & $r>1$ & 0.00 & 0.03 & 4.14 \\
\hline
\end{tabular}

the null hypothesis is that there is no co-integrating vector, both eigenvalue and trace statistics strongly reject the null hypothesis. When the null hypothesis is that there is a single co-integrating vector, both eigenvalue and trace statistics fail to reject the null hypothesis.

Therefore, there is an indication of a co-integrating relationship between the variables with rank of one. After testing, it shows that the trace test values are greater than critical values at the $5 \%$ level when the null hypothesis is " $r=0$ ". The results imply that co-integration exists in the US, China, Australia, Turkey and Benin. When we test the rank value, it is insignificant or fails to reject that the rank $(H)$ is greater than 1 in the above countries. In other words, we can say that there is cointegration in the United States, China, Australia, Turkey and Benin and we fail to reject that rank is equal to 1 based on the trace test. For Mali, Chad, Brazil and Pakistan, we fail to reject the co-integration relationship between those countries' cotton prices and the NYCE futures price.

To test between the three models, this paper uses the variance reduction procedure as explained in section 3.
Table 5 presents the results of the variance reduction. Of the three constant hedge ratios derived from the OLS model, the bivariate VAR model, and the error-correction model, the hedge ratio calculated from the OLS regression model performs the worst in terms of reducing portfolio variance, especially for major cotton players such as the United States, China, Brazil, and Australia. The error correction model gives the largest variance reduction for the United States, China, Brazil, and Australia. For the Africa Franc Zone countries, Egypt, Turkey, Pakistan, India, and Brazil, there is a weak relationship between domestic cotton prices and NYCE futures prices, implying a non-statistically significant variance reduction as shown by the results.

The parameter estimates of the error correction model are summarized in Table 6. ${ }^{2}$ The error correction models were estimated by incorporating the error correction term into the VAR model. For both equations of changes in domestic farm prices and changes in futures price, the coefficients of the error-correction term are statistically

${ }^{2}$ The results of the regression of the OLS and bivariate VAR models are not presented here but can be obtained from the authors upon request. 
Table 5. Comparison of Variance Reduction from the Three Models.

\begin{tabular}{cccc}
\hline Country & V.R in OLS model & V.R in VAR model & V.R in Error correction Model \\
\hline US & 0.42 & 0.42 & 0.44 \\
China & 0.23 & 0.24 & 0.25 \\
Brazil & 0.11 & 0.12 & 0.15 \\
Australia & 0.22 & 0.23 & 0.29 \\
Turkey & 0.03 & 0.03 & 0.04 \\
India & -0.01 & -0.03 & -0.03 \\
Pakistan & 0.09 & 0.07 & 0.07 \\
Egypt & 0.01 & 0.01 & 0.01 \\
Benin & 0.00 & 0.00 & -0.03 \\
Burkina F & 0.01 & 0.01 & -0.03 \\
Chad & 0.00 & 0.00 & -0.02 \\
Mali & 0.00 & -0.01 & 0.00 \\
\hline
\end{tabular}

Notes: Co-integration LR Test Based on Maximal Eigenvalue of the Stochastic Matrix and Trace of the Stochastic Matrix. $r$ represents the number of linearly independent co-integrating vectors.

Table 6. Estimated Hedging Ratios.

\begin{tabular}{ccccc}
\hline Hedge Ratio of country & Number of Observation & Traditional Model & Bivariate VAR Model & Error Correction Model \\
\hline US & 32 & 0.58 & 0.60 & 0.67 \\
Australia & 32 & 0.73 & 0.83 & 0.52 \\
China & 28 & 0.42 & 0.48 & 0.97 \\
India & 32 & 0.10 & 0.20 & 0.23 \\
Pakistan & 32 & 0.04 & 0.03 & 0.03 \\
Brazil & 18 & 0.10 & 0.10 & 0.15 \\
Turkey & 32 & 0.07 & 0.06 & 0.23 \\
Egypt & 32 & 0.20 & 0.17 & 0.17 \\
Benin & 27 & -0.01 & 0.01 & 0.03 \\
Burkina F & 32 & -0.04 & -0.03 & 0.03 \\
Chad & 27 & -0.02 & 0.00 & -0.03 \\
Mali & 32 & 0.00 & 0.02 & -0.01 \\
\hline
\end{tabular}

significant, as indicated by the large values of the $t$-ratios. The statistical significance of the long-run estimated parameter indicates that the error correction term is correctly signed in both equations and implies that spot prices have a much greater speed of adjustment than the futures price. The results of estimated long-run parameters are significant in the US, China, Australia and Pakistan. The results indicate that there is co-integration between the spot prices in these countries and the NYCE futures price.

We cannot, however, reach the same conclusion for the Africa Franc Zone countries, Egypt, India, Brazil, and Turkey. The results are not statistically significant in these countries, we do not find any co-integration relationship and we cannot determine whether there exists any long run relationship between the spot prices in these countries and the NYCE futures price.

\subsection{Hedge Ratio Results}

Using the variance and covariance of the residuals, the hedge ratios of the three models are calculated in Table 5. As expected, and in line with most of the previous studies by Ghosh (1993) [23] and others, the hedge ratios estimated by the error-correction model are greater than those obtained from other models in most of the cases except Australia. This is because co-integration exists between futures prices and spot prices; ignoring this fact would imply that the hedger should take a smaller than optimal futures position.

In addition, the results indicate that countries with higher market power such as the United States and China, and countries without many market distortions, such as Australia, have higher hedging ratios than the other countries such as India, Turkey, Brazil and Egypt. On the 
Table 7. Estimate of the Error Correction model.

\begin{tabular}{|c|c|c|c|c|c|}
\hline \multirow{2}{*}{ country } & & \multicolumn{2}{|c|}{ First Difference of Domestic Price } & \multicolumn{2}{|c|}{ First difference of New York future price } \\
\hline & & Coefficient & $t$-value & Coefficient & $t$-value \\
\hline \multirow[t]{8}{*}{ US } & Constant & 0.28 & 0.19 & 0.71 & 0.37 \\
\hline & $\Delta \mathrm{CP}_{t-1}$ & -0.37 & -1.21 & 0.41 & 1.08 \\
\hline & $\Delta \mathrm{FP}_{t-1}$ & 0.32 & 1.29 & -0.03 & -0.11 \\
\hline & $\mathrm{LCP}_{t-1}$ & 0.67 & 4.48 & 1.08 & 5.80 \\
\hline & $\mathrm{LFP}_{t-1}$ & -1.40 & -4.48 & -2.26 & -5.80 \\
\hline & \multicolumn{2}{|c|}{ Long-run Parameter beta } & & & \\
\hline & $\mathrm{CP}$ & 1 & & & \\
\hline & FP & -2.09 & -2.07 & & \\
\hline \multirow[t]{8}{*}{ Australia } & Constant & -0.06 & -0.03 & 0.66 & 0.35 \\
\hline & $\Delta \mathrm{CP}_{t-1}$ & -0.21 & -1.29 & 0.61 & 4.06 \\
\hline & $\Delta \mathrm{FP}_{t-1}$ & 0.49 & 2.24 & -0.34 & -1.72 \\
\hline & $\mathrm{LCP}_{t-1}$ & -0.12 & -5.55 & -0.10 & -5.12 \\
\hline & $\mathrm{LFP}_{t-1}$ & -1.53 & -5.55 & -1.27 & -5.12 \\
\hline & \multicolumn{2}{|c|}{ Long-run Parameter beta } & & & \\
\hline & $\mathrm{CP}$ & 1 & & & \\
\hline & FP & 12.37 & 8.09 & & \\
\hline \multirow[t]{8}{*}{ China } & Constant & 0.31 & 0.09 & 0.51 & 0.20 \\
\hline & $\Delta \mathrm{CP}_{t-1}$ & -0.21 & -0.72 & -0.38 & -1.79 \\
\hline & $\Delta \mathrm{FP}_{t-1}$ & -0.34 & -1.13 & 0.14 & 0.61 \\
\hline & $\mathrm{LCP}_{t-1}$ & -0.32 & -0.85 & 1.09 & 3.86 \\
\hline & $\operatorname{LFP}_{t-1}$ & 0.46 & 0.85 & -1.58 & -3.86 \\
\hline & \multicolumn{2}{|c|}{ Long-run Parameter beta } & & & \\
\hline & $\mathrm{CP}$ & 1 & & & \\
\hline & FP & -1.45 & -3.15 & & \\
\hline \multirow[t]{8}{*}{ India } & Constant & 2.36 & 1.86 & 0.61 & 0.20 \\
\hline & $\Delta \mathrm{CP}_{t-1}$ & 0.34 & 2.18 & -0.67 & -1.76 \\
\hline & $\Delta \mathrm{FP}_{t-1}$ & -0.21 & -2.67 & -0.50 & -2.65 \\
\hline & $\mathrm{LCP}_{t-1}$ & -1.83 & -6.63 & 0.33 & 0.49 \\
\hline & $\mathrm{LFP}_{t-1}$ & 0.59 & 6.63 & -0.11 & -0.49 \\
\hline & \multicolumn{2}{|c|}{ Long-run Parameter beta } & & & \\
\hline & $\mathrm{CP}$ & 1 & & & \\
\hline & FP & -0.32 & -0.55 & & \\
\hline \multirow[t]{8}{*}{ Pakistan } & Constant & -0.02 & -0.08 & 1.08 & 0.54 \\
\hline & $\Delta \mathrm{CP}_{t-1}$ & -0.63 & -3.71 & -3.96 & -2.77 \\
\hline & $\Delta \mathrm{FP}_{t-1}$ & 0.01 & 0.68 & 0.43 & 2.44 \\
\hline & $\mathrm{LCP}_{t-1}$ & 0.12 & 1.76 & 4.00 & 6.95 \\
\hline & $\mathrm{LFP}_{t-1}$ & -0.06 & -1.76 & -1.97 & -6.95 \\
\hline & \multicolumn{2}{|c|}{ Long-run Parameter beta } & & & \\
\hline & $\mathrm{CP}$ & 1 & & & \\
\hline & FP & -0.49 & -4.10 & & \\
\hline
\end{tabular}




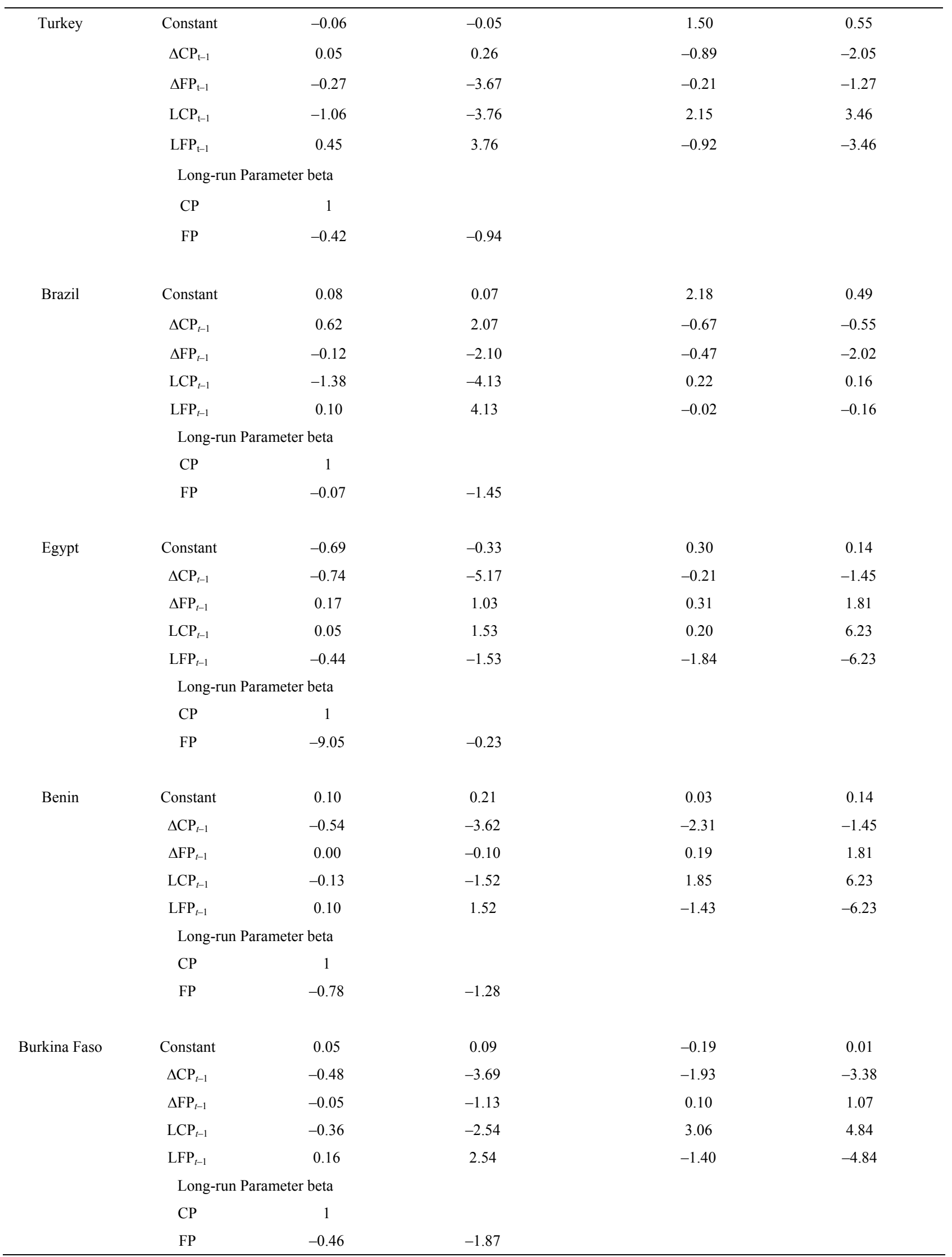




\begin{tabular}{|c|c|c|c|c|c|}
\hline \multirow[t]{8}{*}{ Chad } & Constant & 0.02 & 0.04 & 0.23 & 0.10 \\
\hline & $\Delta \mathrm{CP}_{t-1}$ & -0.35 & -2.07 & 0.55 & 0.64 \\
\hline & $\Delta \mathrm{FP}_{t-1}$ & 0.05 & 1.34 & 0.28 & 1.55 \\
\hline & $\mathrm{LCP}_{t-1}$ & 0.03 & 0.58 & -1.54 & -5.78 \\
\hline & $\mathrm{LFP}_{t-1}$ & 0.03 & 0.58 & -1.76 & -5.78 \\
\hline & \multicolumn{3}{|c|}{ Long-run Parameter beta } & & \\
\hline & $\mathrm{CP}$ & 1 & & & \\
\hline & FP & 1.15 & 0.57 & & \\
\hline \multirow[t]{8}{*}{ Mali } & Constant & 0.04 & 0.11 & 1.05 & 0.48 \\
\hline & $\Delta \mathrm{CP}_{t-1}$ & -0.41 & -2.55 & 0.38 & 0.44 \\
\hline & $\Delta \mathrm{FP}_{t-1}$ & 0.08 & 2.80 & 0.09 & 0.55 \\
\hline & $\mathrm{LCP}_{t-1}$ & -0.14 & -1.39 & -2.70 & -5.14 \\
\hline & $\mathrm{LFP}_{t-1}$ & -0.08 & -1.39 & -1.49 & -5.14 \\
\hline & \multicolumn{2}{|c|}{ Long-run Parameter beta } & & & \\
\hline & $\mathrm{CP}$ & 1 & & & \\
\hline & FP & 0.55 & 0.20 & & \\
\hline
\end{tabular}

contrary, there is not much improvement or significant change for the hedge ratios among the three regression models for countries like Egypt and the Africa Franc Zone countries. It can be concluded that for countries that are without market power as well as subject to significant domestic policy distortions, the NYCE futures market price is not a good target for hedging. These results are consistent with Varangis et al. (1993) [8] who find that the New York futures market does not provide an appropriate mechanism for hedging the price risk in Egyptian cotton.

\section{Conclusions}

This paper aims at estimating the hedge ratios for cotton production across different countries and determining whether New York Cotton Exchange futures prices can serve as a hedging tool for cotton producers in these countries. Three econometric models were used: ordinary least squares, bivariate vector autoregressive, and error correction models. The variance reduction test results indicate that the error correction model outperforms the ordinary least squares and the bivariate vector autoregressive models.

The results of the error correction model indicate that spot prices have a much greater speed of adjustment than the futures price. In addition, the results indicate that there is co-integration between the spot prices and the NYCE futures prices in the United States, Australia, and China; while for Africa Franc Zone countries, the results were not significant.

With respect to the hedge ratio, the findings of this paper show that, overall, the hedge ratios implied by the error correction model are larger than the ones implied by the ordinary least squares and the bivariate VAR models. The countries studied can, additionally, be grouped into three categories based on the hedge ratios. In the first, we find countries with higher market power, such as the US and China, and countries without market distortions, such as Australia. For these countries, the New York Cotton Exchange futures prices can serve as a hedging tool for cotton producers as indicated by high hedge ratio values. In the second category, we find developing countries, such as Turkey, Brazil, India, and Egypt with intermediate values of hedge ratios. Though the NYCE futures prices cannot be used as a hedging tool for cotton spot prices in these countries, we may conclude from the results that in the future, the NYCE futures prices will have a bigger impact. Finally, for less developed countries, such as Africa Franc Zone countries, and Pakistan, the NYCE futures prices cannot serve as hedging tool against the risks faced by cotton farmers.

\section{References}

[1] K. Hussein, L. Hitimana and C. Perret, "Cotton in West Africa-The Economic and Social Stakes," The Development Dimension Series, OECD, Paris, 2005.

[2] D. Irwin, "Free Trade under Fire," Princeton University Press, New Jersey, 2002.

[3] R. MacDonald, "Concepts to Calculate Equilibrium Exchange Rates: An Overview," Discussion Paper, Deutsche Bundesbank, Research Centre, Series 1, 2000.

[4] Foreign Agricultural Service, 2008. http://www.fas.usda.gov/scriptsw/attacherep/default.asp 
[5] G. Estur, "Commodity Risk Management Approaches for Cotton in West Africa," 2004. http://www.icac.org/cotton_info/speeches/estur/2004/com risk_man_04.pdf

[6] Business News, 2006. http://business-school-blog.elliottback.com/34/world-bank-e xpects-5-annual-depreciation-in-us-dollar-till-2000\%20

[7] World Trade Organization, "Poverty Reduction: Sectoral Initiative in Favor of Cotton," Joint Proposal by Benin, Burkina Faso, Chad, and Mali, Committee on Agriculture, Special Session, TN/AG/GEN/4, May 16, 2003.

[8] P. Varangis, E. Thigpen and S. Satyanarayan, "The Use of New York Cotton Futures Contracts to Hedge Cotton Price Risk in Developing Countries," Working Paper \# 1328, Policy Research, 1994.

[9] W. Zant, "Stockholding, Price Stabilization and Futures Trading: Some Empirical Investigations of the Indian Natural Rubber Market. International Books van Arkel," Utrecht, Netherlands, 1998.

[10] World Bank, "Dealing with Commodity Price Volatility in Developing Countries: A Proposal for a Market Based Approach," International Task Force on Commodity Risk Management in Developing Countries, Washington, DC. 1999.

[11] L. L. Johnson, "The Theory of Hedging and Speculation in Commodity Futures," Review of Economic Studies, Vol. 27, No. 3, 1960, pp. 139-151. doi:org/10.2307/2296076

[12] J. L. Stein, "The Simultaneous Determination of Spot and Future Prices," American Economic Review, Vol. 59, No. 5, 1961, pp. 1012-1025.

[13] D. M. Holthausen, "Hedging and the Competitive Firm under Price Uncertainty," American Economic Review, Vol. 69, No. 5, 1979, pp. 989-995.

[14] S. H. Lence, K. L. Kimle and M. L. Hayenga, "A Dynamic Minimum Variance Hedge," American Journal of Agricultural Economics, Vol. 75, No. 4, 1993, pp. 10631071. doi:org/10.2307/1243994

[15] L. H. Ederington, "The Hedging Performance of the New Futures Markets," Journal of Finance, Vol. 34, No. 1, 1979, pp. 157-170. doi:org/10.2307/2327150

[16] K. H. Kahl, "Determination of the Recommended Hedging Ratio," American Journal of Agricultural Economics, Vol. 65, No. 3, 1983, pp. 603-605. doi:org/10.2307/1240514

[17] S. Benninga, R. Eldor and I. Zilcha, "Optimal Hedging in the Futures Market under Price Uncertainty," Economic Letters, Vol. 13, No. 2-3, 1983, pp. 141-145. doi:org/10.1016/0165-1765(83)90076-9

[18] C. L. Jones, "Theory of Hedging on Beef Futures Mar- ket," American Journal of Agricultural Economics, Vol. 50, No. 5, 1968, pp. 1760-1766. doi:org/10.2307/1237383

[19] K. H. Mathews and Holthausen, "A Simple Multi-Period Minimum Risk Hedge Model," American Journal of Agricultural Economics, Vol. 73, No. 4, 1991, pp. 10201026. doi:org/10.2307/1242429

[20] R. M. Leuthold, J. C. Junkus and J. E. Cordier, "The Theory and Practice of Futures Markets," Lexington Books, Lexington, MA, 1989.

[21] A. F. Herbst, D. D. Kare and J. F. Marshall, "A Time Varying Convergence Adjusted Minimum Risk Futures Hedge Ratio," Advances in Futures and Options Research, Vol. 6, 1993, pp. 137-155.

[22] W. Yang and D. Allen, "Multivariate GARCH Hedge Ratios and Hedging Effectiveness in Australian Futures Markets," Accounting and Finance, Vol. 45, No. 2, 2005, pp. 301-321. doi:org/10.1111/j.1467-629x.2004.00119.x

[23] A. Ghosh, "Co-Integration and Error Correction Models: Intertemporal Causality between Index and Futures Prices," The Journal of Futures Markets, Vol. 13, No. 2, 1993, pp. 193-198. doi:org/10.1002/fut.3990130206

[24] D. D. Lien and X. Luo, "Estimating Multi-Period Hedge Ratios in Co-Integrated Markets," The Journal of Futures Markets, Vol. 13, No. 8, 1993, pp. 909-920. doi:org/10.1002/fut.3990130808

[25] D. D. Lien, "The Effect of the Co-Integrating Relationship on Futures Hedging: A Note," The Journal of Futures Markets, Vol. 16, No. 7, 1996, pp. 773-780. doi:org/10.1002/(SICI)1096-9934(199610)16:7<773::AI D-FUT3>3.0.CO;2-L

[26] R. T. Baillie and R. J. Myers, "Bivariate GARCH Estimation of the Optimal Commodity Futures Hedge," Journal of Applied Econometrics, Vol. 6, No. 2, 1991, pp. 109-124. doi:org/10.1002/jae.3950060202

[27] H. Y. Park and A. K. Bera, "Interest Rate Volatility, Basis, and Heteroscedasticity in Hedging Mortgages," The American Real Estate and Urban Economics Association Journal, Vol. 15, No. 2, 1987, pp. 79-97.

[28] V. Levy, "The Welfare and Transfer Effects of Cotton Price Policies in Egypt, 1965-1978," American Journal of Agricultural Economics, Vol. 65, No. 3, 1965, pp. 576580. doi:org/10.2307/1240509

[29] D.A. Dickey and W.A. Fuller, "Likelihood Ratio Statistics for Autoregressive Time Series with a Unit Root," Econometrica, Vol. 49, No. 4, 1981, pp. 1057-1072.

[30] S. Johansen and K. Juselius, "Maximum Likelihood Estimation and Inference on Co-Integration with Application to the Demand for Money," Journal of Econometrics, Vol. 53, No. 2, 1990, pp. 211-244. 